following $\mathrm{N}$-terminal amino acids appeared: aspartic acid, glycine, alanin, lysine and methionine. The glutamyl and tyrosyl residues did not show any significant change during the digestion time used. As the value of tyrosine was practically constant during the fibrinogenolysis, the released amounts of the $\mathrm{N}$-terminal amino acids were expressed in relation to tyrosine (see Fig. 1). When the digestion of fibrinogen had proceeded so far that only traces could be coagulated with trombin, approximately one mole lysyl, two moles each of glycyl, aspartyl and methionyl, and three moles alanyl residues were formed from one mole of fibrinogen.

1. Edman, P. Acta Chem. Scand. 4 (1950) 283.

2. Blombäck, B., Blombäck, M., Senning, A. and Wallén, P. Nord. Med. 53 (1955) 1019.

3. Saifer, A. and Newhouse, A. J. Biol. Chem. 208 (1954) 159.

4. Blombäck, B. and Blombäck, M. Arkiv Kemi 10 (1956) 415.

5. Edman, P. and Sjöquist, J. Acta Chem. Scand. 10 (1956) 1507.

6. Sjöquist, J. Acta Chem. Scand. 7 (1953) 447.

7. Blombäck, B. and Yamashina, I. Arkiv Kemi (In print).

8. Blombäck, B. and Yamashina, I. Acta Chem. Scand. 11 (1957) 194.

Received April 23, 1957.

\section{An Antibiotic Related to the Streptothricin Group}

J. A. CHRISTENSEN, O. ROSENLUND HANSEN, ALF LUND, and B. NOER

A/S Ferrosan, Copenhagen, Denmark

$\mathrm{F}^{\mathrm{r}}$ rom an unidentified actinomycete No. 4279 isolated from a soil sample collected in North Zealand, Denmark, in 1953 we have succeeded in isolating a crude substance with antibiotic activity against a wide range of bacteria and fungi. This substance has properties very similar to those described by Schaffner, Rangaswami and Waksman ${ }^{1,2}$ as regards the mycothricin complex though it differs from the latter in certain chemical respects. Optimum yield was obtained after $36 \mathrm{~h}$ at $25-28^{\circ}$ in a medium containing the extractive material from $40 \mathrm{~g}$ of soy-meal per $l$ in an aerated and stirred fermentator.

A crude preparation of the active substance was obtained from the broth by adsorption on activated carbon at $\mathrm{pH} 7-8$ and elution with $80 \%$ ethanol at pH 2.7. Purification was carried out (a) by treating a $20 \%$ aqueous solution of the substance at $\mathrm{pH} 2.7$ with activated carbon and subsequent precipitation by means of 10 volumes of acetone or ethanol and (b) by adsorption on Amberlite IRC-50 at $\mathrm{pH} 8$ and elution with dilute hydrochloric acid; the active fractions were then neutralized with Amberlite IR-4B and evaporated in vacuo or, in some cases, lyofilized.

The substance is readily soluble in water and slightly soluble in ethanol. It is insoluble in chloroform, ether, benzene, toluene and $n$-butanol. Paper chromatograms developed with dilute ethanol at pH 3.0 showed the following $R_{F}$ values: 0.38 (ethanol:water, 80:20), 0.70 (ethanol: water, 70:30), The total activity of the substance can be precipitated by ammonium reineckate, methyl orange, and picric acid, whereas only a fraction of the total activity can be precipitated by flavianic acid ( $\mathrm{pH}$ between 5.0 and 5.5).

The following tests were negative: Ninhydrin, Pauly, Sakaguchi, Hopkins-Cole, Fehling, Tollens, Molisch, 9-hydrazinoacridin for hydrophilic aldehydes ${ }^{3}$. The biuret reaction was dubious. With sodium periodate the substance gave formaldehyde.

On hydrolysis in $2 \mathrm{~N}$ hydrochloric acid an amino acid and a sugar were formed.

Minimum inhibitory concentration

\begin{tabular}{lc}
\hline Test organism & $\mu \mathrm{g} / \mathrm{ml}$ \\
\hline & $0.25-0.31$ \\
Staph. aureus & $12.5-25.0$ \\
E. coli & $1.0-10.0$ \\
Strept. hemolyticus & $1.0-10.0$ \\
S. typhi & $0.1-1.0$ \\
Corynebact. sp. & $0.1-1.0$ \\
B. subtilis & $1.0-10.0$ \\
B. dysenteriae Shiga & $10-100$ \\
Pseud. aeruginosa & $0.12-0.25$ \\
Alternaria circinans & $0.25-0.50$ \\
P. notatum & $1.0-10$ \\
A. niger & $1.0-10$ \\
P. pullulans & $12.5-25$ \\
Candida albicans & $0.25-0.50$ \\
Trichoderma viride & \\
\hline
\end{tabular}


The amino acid has $R_{F} 0.15$ ( $n$-butanol: acetic acid:water, 4:1:5). A sugar test was made in the following way: The substance was heated in a solution of 2,4-dinitrophenylhydrazine in $2 \mathrm{~N}$ hydrochloric acid for a few hours. On cooling, a red precipitate of a tetranitrophenylosazone was formed. On adding a fow drops of $\mathrm{N}$ sodium hydroxide to a solution of the precipitate in ethanol a blue colour was obtained (modified Bamberger reaction ").

The purest product obtained has been tested in broth-dilution assay against different microorganisms.

In mice LD 50 was about $1200 \mathrm{mg} / \mathrm{kg}$ body weight when administered intravenously. In rats $50-500 \mathrm{mg} / \mathrm{kg}$ subcuta. neously caused no acute toxic symptoms but anuria developed after 3 or 4 days. Examination of the kidneys showed severe tubular damage. Unlike streptothricin, a $1 \%$ aqueous solution did not produce local irritation in rabbits' eyes.

1. Schaffner, C. P., Rangaswami, G. and Waksman, S. A. Proc. 3rd Intern. Congr. Biochem., Brussels July 1955 (1956) 55.

2. Rangaswami, G., Schaffner, C. P. and Waksman, S. A. Antibiotics and chemotheraphy 6 (1956) 675.

3. Boxer, G. E. and Jelinek, V. C. J. Biol. Chem. 170 (1947) 491.

4. Bamberger, E. Ber. 32 (1899) 1806.

Received April 16, 1957.
Correction to "Determination of Small Amounts of Total Cholesterol by the Tschugaeff Reaction with a Note on the Determination of Lathosterol" *

HENRIK K. HANEL and HENRIK DAM

Department of Biochemistry and Nutrition, Polytechnic Institute, Copenhagen, Denmark

In Table 3, p. 681 the following corrections are made:

Compound Absorbance mmoles/ml

\begin{tabular}{llll}
\hline$\ldots \ldots \ldots \ldots \ldots \ldots$ & & & \\
Cholesterol & for & 9593 read & $\mathbf{9 0 6 7}$ \\
Cholesterylacetate & for & $\mathbf{8 3 4 9}$ read & $\mathbf{6 3 4 8}$ \\
$\ldots \ldots \ldots \ldots \ldots \ldots$ & & & \\
\hline
\end{tabular}

* Acta Chem. Scand. 9 (1955) 677.

Received April 15, 1957. 